\title{
Effect of rootstock and cultivars on some branch and leaf characteristics in pear ${ }^{*}$
}

\author{
Nermin Coban (iD) ${ }^{1}$, Ahmet Ozturk (iD) ${ }^{1 *}$ \\ ${ }^{1}$ Ondokuz Mayıs University, Faculty of Agriculture, Department of Horticulture, Samsun-Turkey \\ $\uparrow$ This study is derived from a part of Nermin ÇOBAN's master thesis.
}

\begin{abstract}
This study was carried out to determine the effects of different pear and quince rootstocks on some branch and leaf properties of 'Deveci' and 'Williams' pear cultivars at Samsun ecological conditions in 2015-2016 years. The number of lateral branches (number plant' $\left.{ }^{1}\right)$, lateral branch length $(\mathrm{cm})$ and diameter $(\mathrm{mm})$ and branch angle $\left({ }^{\circ}\right)$ and petiole length $(\mathrm{cm})$ and thickness $(\mathrm{mm})$, leaf width and length $(\mathrm{cm})$ and leaf area $\left(\mathrm{cm}^{2}\right.$ leaf $\left.{ }^{-1}\right)$ were examined in the study. Rootstock and cultivar and rootstock x cultivar interaction had significant effects on all examined branch and leaf traits. The 'Deveci' cultivar had generally got better lateral branch characteristics and higher leaf size than the 'Williams'. The highest lateral branch number was observed in the OHxF333 rootstock, while the highest lateral branch diameter was found in the seedlings rootstock. The BA29 rootstock had wider angled branches than the other rootstocks. Leaf area was the highest in OHxF333 rootstock and the lowest in BA29 rootstock. The highest number of lateral branch was determined in the 'Deveci'/Fox11 and the lowest was in the 'Williams'/Fox11 scion/rootstock combinations. The longest lateral branches were detected in the 'Deveci'/BA29 and the 'Deveci'/seedling. The highest leaf area was found in the 'Deveci'/BA29 and 'Williams'/seedling and the lowest was in the 'Williams'/BA29 scion/rootstock combination. As a result, in this study was determined that the cultivars grafted on different rootstocks affect their growth and development by affecting their vegetative growth and morphological traits.
\end{abstract}

\section{ARTICLE HISTORY}

Received: 31 May 2020

Accepted: 12 June 2020

\section{KEYWORDS}

Branch angle

Leaf area

Morphological features

Pear

Petiole dimensions

\section{* CORRESPONDING}

ozturka@omu.edu.tr

\section{Introduction}

In pear cultivation, saplings that are grafted on seedling or clonal rootstocks are generally used (Ozcagiran et al., 2005; Hepaksoy, 2019). In order to make fruit growing profitable and economical and to be further developed, quality saplings should be used in the orchard establishment. These saplings should be produced with a new and high market value cultivars that are accurate, quality, healthy, free from diseases and pests and they should be delivered to the growers in a sufficient number and in a short time (Jackson, 2003; Hancock and Lobous, 2008; Dondini and Sansavini, 2012). Instead of rootstocks with vigor growth and development in today's modern pear cultivation, dwarf or semi-dwarf quince and pear clone rootstocks are used (Hancock and Lobos, 2008; Dondini and Sansavini, 2012; Hepaksoy, 2019). Pear clonal rootstocks show stronger development compared to quince clone rootstocks, so planting distances are wider (Ozcagiran et al., 2005; Sharma et al., 2009; da Silva et al., 2018). Although pears are grown on quince rootstocks with control the growth forces of trees (dwarfing), yield precocity, increase in fruit yield and quality, due to their negative aspects such as sensitivity to winter cold, chlorosis and fire blight in calcareous soils, weak anchorage to soil and poor graft compatibility (Pina and Errea, 2009) instead of Pyrodwarf, OHxF, Farold, Fox, $\mathrm{BP}$ and CTS series developed in different rootstock breeding programs and pear clone rootstocks from some different pear species have been used in recent years (Jackson, 2003; Hancock and Lobous, 2008; Dondini and Sansavini, 2012; da Silva et al., 2018). Rootstocks affects the growth and development of cultivars grafted on, cultivars affect vice versa rootstocks (Webster, 1995; Jackson, 2003). Rootstock affects grafted on the cultivar characteristics such as flowering, earliness, productivity, fruit size, biochemical properties of fruits, fruit quality, shoot growth and development, leaf size and branching (Warner, 1991; Webster, 1995; Jackson, 2003; Ozturk and Ozturk, 2014; Karlidag et al., 2016; Gundogdu, 2019; Serttas and Ozturk, 2019). In pear cultivation, wide-angled saplings with high quality, well-developed lateral branches are preferred. For this purpose, branched saplings with wide-angled lateral branches, which begin early yield instead of whips saplings, are preferred by the producers. Rootstocks affect the sapling quality by affecting on the number and development of lateral branch (Warner, 1991; Sahin, 2014; Karlidag et al., 2016). 
New pear rootstocks were improved many years later in different breeding programs (da Silva et al., 2018; Hepaksoy, 2019). It is important for pear cultivation to investigate the effects of these new pear rootstocks on the growth and development forces of the cultivars grafted on rootstocks, as well as their resistance to biotic and abiotic stress conditions. It is desired that rootstocks have a good root system, which affects the longevity of plants and high quality fruit. In addition to choosing a good cultivar for successful cultivation, selection of suitable rootstocks for growing conditions is also very important (Hepaksoy, 2019). The effect of cultivars grafted on rootstocks on growth characteristics determines the growing ability of the cultivars. In this respect, to reveal how the rootstocks affect the morphological characteristics of the cultivars grafted on the rootstocks (Rahman et al., 2017; da Silva et al., 2018) is very important for the pear producer that will grow with these saplings.

The aim of the study was aimed to determine the effect of different rootstocks and cultivars on some branch and leaf characteristics of grafted pear saplings.

\section{Materials and methods}

\subsection{Experiment location}

The study was carried out at Agriculture Research Station of Ondokuz Mayıs University, Atakum (North: 41 $21^{\prime}$, East: 36 $11^{\prime}$, Altitude: $173 \mathrm{~m}$ ) during 2015 and 2016 years, Samsun (Turkey). The study was conducted in nursery parcel located in the open field. Grafting was also performed in open field. The research area was flat and had a slope of about $1 \%$. The nursery soil structure was clayed-loam and weakly acidic and it was lime-free, unsalted, rich in terms of phosphorus and potassium and organic matter. The plants were mulched against the weeds and drip irrigation was implemented them.

The climate of Samsun proves its temperate climate character. According to long term climatically data of Samsun, the highest average temperature was $27.0^{\circ} \mathrm{C}$, the lowest temperature was $3.9^{\circ} \mathrm{C}$, the annual average temperature was $14.4^{\circ} \mathrm{C}$, and the average annual rainfall was $733 \mathrm{~mm}$. According to the obtained data, a large part of the precipitation falls in autumn and winter (TSMS, 2020).

\subsection{Plant materials}

In the study, one-year old clonal rootstocks of quince (Quince BA 29), pear (OHxF 333 and Fox 11) and pear seedling were used. Rootstocks were planted a distance of $120 \mathrm{~cm}$ and $30 \mathrm{~cm}$ in February 2014 and cultivated in open field. 'Deveci' and 'Williams' pear cultivars were used as scions. 'Deveci' cultivar is compatible with quince and pear rootstocks (Ozcagiran et al., 2005) and 'Williams' is incompatible or moderate compatible with quince rootstock (Gulen et al., 2002; Hudina et al., 2014)

\subsection{Grafting and observations}

Similar sized (for thickness) rootstocks were selected for grafting. T-budding method, which is the most suitable graft method in the fall period (Westwood 1995; Hartmann et al. 2011) was used in the month of 1st September, 2014 and 2015. Grafting was performed $20 \mathrm{~cm}$ above the soil surface (Lewis and Alexander 2008; Hartmann et al. 2011). A total of 30 grafts was made in the study, 3 replicates included 10 grafting in each rootstock and cultivar combination. White colored, soft and silicone grafting tape was used to protect the graft area. Cultivation factors such as irrigation, weed management and removal of suckers below the graft union were preformed regularly. As a cover mulch, black colored and UV-added, polypropylene produced, was used between the rows for weed control. The rootstocks used in the study were irrigated during summer by drip irrigation systems. Fertilization was done fertigation, and NPK (20.10.20+ME, 3-4 kg decare ${ }^{-1}$ ) fertilizer was used, one month intervals. Chemical spraying was not performed in the orchard.

After 20 days of budding brown and black and shriveled buds were taken as dead, but green buds indicated bud take (Hartmann et al., 2011). In the study, some vegetative growth characteristics, such as lateral branch number (number plant $\left.{ }^{1}\right)$ and lateral branch diameter ( $\mathrm{mm}$ ) and lateral branch length $(\mathrm{cm})$ and branch angle $\left(^{\circ}\right)$ and leaf dimensional traits, were determined according to previous relevant studies (Ozturk and Ozturk., 2014; Sahin, 2014; Rahmati et al., 2015; Karlidag et al., 2016; Rahman et al., 2017). Lateral branch number (number plant ${ }^{-1}$ ) was determined by counting lateral branches from the graft shoot at the end of vegetation (December $1^{\text {st}}$ ) in all sapling for each cultivar/rootstock combination. Lateral branch length $(\mathrm{cm})$ was measured by meter from trunk to shoot tip at the end of vegetation (December $1^{\text {st }}$ ) in all sapling for each cultivar/rootstock combination. Lateral branch diameter $(\mathrm{mm})$ was measured by $0.01 \mathrm{~mm}$ sensitive digital caliper at $5 \mathrm{~cm}$ distance from the main stem in the lateral branch at the end of vegetation (December $1^{\text {st }}$ ) in all sapling for each cultivar/rootstock combination. Branch angle (o) was measured with a goniometer at each lateral branch on the main stem at the end of the vegetation period (December $1^{\text {st }}$ ) in all sapling for each cultivar/rootstock combination. Leaf lamina width $(\mathrm{cm})$ and length $(\mathrm{cm})$ and leaf petiole length $(\mathrm{cm})$ and thickness $(\mathrm{mm})$ were determined according to Ozturk and Ozturk (2014). Leaf area was determined according to the equation suggested by Ozturk et al. (2017).

\subsection{Data analysis}

This study was arranged with randomized complete block design with three replications, each replication contained 10 plants, and totally each treatment had 30 plants. Data analyses were performed using SPSS v 21.0 (IBM ${ }^{\circledR}$ SPSS ${ }^{\circledR}$ statistics) statistical package program via the license of Ondokuz Mayis University. The differences between the averages of rootstocks and cultivars and their interaction were determined by 'Duncan's Multiple Range Tests' at the $0.05 \%$ levels. The results are given as two-year average in the tables.

\section{Results}

\subsection{Branch characteristics}

In this study, the number of lateral branches, lateral branch length, lateral branch diameter, lateral branch angle, leaf width, leaf length, average leaf area, petiole length and diameter were investigated among some pear varieties grafted on different rootstocks and they presented in Table 1 and Table 2. 


\subsubsection{Lateral branch number}

The lateral branch number was found to be higher in the OHxF333 (19.7 number plant ${ }^{-1}$ ) than the other rootstocks in terms of average of rootstocks in the stud. The 'Deveci' cultivar had a higher lateral branch number than the 'Williams' cultivar. It was observed that the highest number of lateral branches in the main shoot was in 'Deveci'/Fox11
(23.67 19.7 number plant $^{-1}$ ) and the lowest was in the 'Williams'/Fox11 (7.33 19.7 number plant ${ }^{-1}$ ). Rootstocks had no effect on the number of lateral branches in the 'Deveci' cultivar. The 'Williams' cultivar had the highest number of lateral branches on the $\mathrm{OHxF} 333$ and the lowest on the Fox11 rootstock (Table 1).

Table 1. The effect of different rootstocks on branch characteristics of pear saplings

\begin{tabular}{|c|c|c|c|c|c|}
\hline Cultivars & Rootstock & $\begin{array}{l}\text { Lateral branch } \\
\text { number } \\
\text { (number plant }^{-1} \text { ) }\end{array}$ & $\begin{array}{l}\text { Lateral branch } \\
\text { length }(\mathrm{cm})\end{array}$ & $\begin{array}{l}\text { Lateral branch } \\
\text { diameter }(\mathrm{mm})\end{array}$ & Branch angle $\left({ }^{\circ}\right)$ \\
\hline \multirow[t]{4}{*}{ Deveci } & BA29 & $19.61 b^{*} A^{* *}$ & $32.7 \mathrm{a} \quad \mathrm{A}$ & $6.26 \mathrm{a} \quad \mathrm{A}$ & $29.0 \mathrm{~cd} \mathrm{~B}$ \\
\hline & Fox11 & $23.67 \mathrm{a}$ & $28.3 \mathrm{ab} \mathrm{A}$ & 5.29 de D & $29.6 \mathrm{~cd} \mathrm{~B}$ \\
\hline & $\mathrm{OH} x \mathrm{~F} 333$ & $18.73 \mathrm{~b} \quad \mathrm{~A}$ & $30.0 \mathrm{ab} \mathrm{A}$ & $5.58 \mathrm{c} \quad \mathrm{C}$ & $37.4 \mathrm{ab} \quad \mathrm{A}$ \\
\hline & Seedling & $19.73 \mathrm{~b} \quad \mathrm{~A}$ & $30.7 \mathrm{a} \quad \mathrm{A}$ & $5.88 \mathrm{~b} \quad \mathrm{~B}$ & $39.3 \mathrm{a} \quad \mathrm{A}$ \\
\hline \multirow[t]{4}{*}{ Williams } & BA29 & $13.11 \mathrm{c} \quad \mathrm{B}$ & $21.3 \mathrm{~d} \quad \mathrm{~B}$ & $5.16 \mathrm{e} \quad \mathrm{C}$ & $22.6 \mathrm{~d} \quad \mathrm{D}$ \\
\hline & Fox11 & $7.33 \mathrm{~d} \quad \mathrm{C}$ & $30.0 \mathrm{ab} \mathrm{A}$ & $5.38 \mathrm{~d} \quad \mathrm{~B}$ & $38.3 \mathrm{a} \quad \mathrm{A}$ \\
\hline & $\mathrm{OH} x \mathrm{~F} 333$ & $20.67 \mathrm{ab} A$ & $25.0 \mathrm{bc} A \mathrm{AB}$ & $5.34 \mathrm{~d} \quad \mathrm{~B}$ & $25.4 \mathrm{~cd} \mathrm{C}$ \\
\hline & Seedling & $11.33 \mathrm{c} \quad \mathrm{B}$ & $21.0 \mathrm{~d} \quad \mathrm{~B}$ & $5.81 \mathrm{~b} \quad \mathrm{~A}$ & $31.1 \mathrm{bc} \quad \mathrm{B}$ \\
\hline \multicolumn{6}{|c|}{ Factors' means } \\
\hline \multirow[t]{4}{*}{ Rootstocks } & BA29 & $16.36 \mathrm{~b}$ & $27.0 \mathrm{a}$ & $5.71 \mathrm{~b}$ & $25.8 \mathrm{~b}$ \\
\hline & Fox11 & $15.50 \mathrm{~b}$ & $29.2 \mathrm{a}$ & $5.34 \mathrm{~d}$ & $34.0 \mathrm{a}$ \\
\hline & $\mathrm{OH} x \mathrm{~F} 333$ & $19.70 \mathrm{a}$ & $27.5 \mathrm{a}$ & $5.46 \mathrm{c}$ & $31.4 \mathrm{a}$ \\
\hline & Seedling & $15.53 \mathrm{~b}$ & $25.8 \mathrm{a}$ & $5.85 \mathrm{a}$ & $35.2 \mathrm{a}$ \\
\hline \multirow[t]{2}{*}{ Cultivars } & Deveci & $20.44 \mathrm{a}$ & $30.4 \mathrm{a}$ & $5.75 \mathrm{a}$ & $33.8 \mathrm{a}$ \\
\hline & Williams & $13.11 \mathrm{~b}$ & $28.0 \mathrm{~b}$ & $5.48 \mathrm{~b}$ & $32.1 \mathrm{~b}$ \\
\hline
\end{tabular}

*: The difference between the means indicated by the same letter in the same column is not statistically significant in the $\mathrm{p}<0.05$.

$* *$ : The difference between the means of the same cultivar indicated by the same capital letter in the same column is not statistically significant in the $\mathrm{p}<0.05$.

\subsubsection{Lateral branch length}

There were significant effects of cultivars and rootstock $\mathrm{x}$ cultivar interaction on the lateral branch length and the effect of rootstocks was insignificant in the study. The averages of the lateral branch length of the rootstock and cultivar were $25.8-29.2 \mathrm{~cm}$ and 28.0-30.4 respectively. The 'Deveci' cultivar had longer side branches than the 'Williams'. The longest lateral branches were found to be in the 'Deveci'/BA29 (32.7 cm) and 'Deveci'/seedling $(30.7 \mathrm{~cm})$, the shortest was in the 'Williams'/BA29 $(21.3 \mathrm{~cm})$ and 'Williams'/seedling $(21.0 \mathrm{~cm})$. The rootstocks did not have any effect on the lateral branch length in the 'Deveci' cultivar. Lateral branch length was the highest $(30.0 \mathrm{~cm})$ saplings grafted on the 'Williams'/Fox11, and the lowest lateral branch length was on saplings grafted on the BA29 and the seedling rootstocks $(21.3 \mathrm{~cm}$ and $21.0 \mathrm{~cm}$ respectively) (Table 1).

\subsubsection{Lateral branch diameter}

In the study, rootstocks, cultivars and rootstock x cultivar interaction had statistically important effect on the lateral branch diameter. The lateral branch diameters of rootstock and cultivar were between 5.34-5.85 and 5.48-5.75 respectively. The thickest lateral branches were found on the seedling rootstock $(5.85 \mathrm{~mm})$ and the thinnest was found on the Fox11 $(5.34 \mathrm{~mm})$ rootstock. The 'Deveci' cultivar had thicker lateral branches than the 'Williams'. The thickest lateral branches were found to be in the 'Deveci'/BA29 (6.26 $\mathrm{mm}$ ) and the thinnest was in the 'Williams'/BA29 (5.16 mm). In the 'Deveci' cultivar, the thickest side branches were found in the BA29 $(6.26 \mathrm{~mm})$ and the thinnest in the Fox11 (5.29 $\mathrm{mm}$ ) rootstock. The lateral branch diameter of the 'Williams' cultivar was the highest on the seedling rootstock $(5.81 \mathrm{~mm})$ and the lowest $(5.16 \mathrm{~mm}$ ) on the BA29 (Table 1).

\subsubsection{Lateral branch angle}

In this study, rootstocks and cultivars and rootstock $\mathrm{x}$ cultivar interaction have a significant effect on the angle of the lateral branches with the main stem in the saplings. The lateral branch angles of the rootstock and cultivar were between 25.8 and $35.2^{\circ}, 32.1$ and $33.8^{\circ}$ respectively. The lateral branch angles of pear rootstock were higher than the quince clone rootstock. The saplings of the 'Deveci' cultivar had a higher lateral branch angle than the 'Williams' cultivar. The highest lateral branch angle was found to be in the 'Deveci'/seedling $\left(39.3^{\circ}\right)$ and 'Williams'/Fox $11\left(38.3^{\circ}\right)$, while the lowest was in the 'Williams'/BA29 $\left(22.6^{\circ}\right)$. In the 'Deveci' cultivar, the highest lateral branch angle was found in the seedling $\left(39.3^{\circ}\right)$ and the $\mathrm{OHxF} 333\left(37.4^{\circ}\right)$ rootstocks and the lowest was in the Fox11 (29.6o) and the BA29 $\left(29.0^{\circ}\right)$ rootstocks. The highest lateral branch angles of 'Williams' cultivar was observed in the Fox $11\left(38.3^{\circ}\right)$ and the lowest was in the BA29 $\left(22.6^{\circ}\right)$ rootstock (Table 1). 


\subsection{Leaf Characteristics}

\subsubsection{Leaf width}

The leaf width was $3.5-3.8 \mathrm{~cm}$ in the rootstock and it was $3.6-3.7 \mathrm{~cm}$ in the cultivar. The leaf width was lower in the BA29 quince rootstock than the other rootstocks.
The leaf width of the "Williams" cultivar $(3.7 \mathrm{~cm})$ was higher than the 'Deveci' $(3.6 \mathrm{~cm})$. In the 'Williams' cultivar, in terms of rootstock $\mathrm{x}$ cultivar interaction, the highest leaf width was on saplings grafted on the seedling and the OHxF333 $(4.0 \mathrm{~cm}$ and $3.9 \mathrm{~cm})$, and the lowest was on the BA29 $(3.3 \mathrm{~cm})($ Table 2$)$.

Table 2. The effect of different rootstocks on leaf characteristics of pear saplings

\begin{tabular}{|c|c|c|c|c|c|c|}
\hline Cultivars & Rootstock & Leaf width $(\mathrm{cm})$ & Leaf length $(\mathrm{cm})$ & Petiole diameter $(\mathrm{mm})$ & Petiole length $(\mathrm{cm})$ & Leaf area $\left(\mathrm{cm}^{2}\right)$ \\
\hline \multirow[t]{4}{*}{ Deveci } & BA29 & $3.6 \mathrm{bc}^{*} \mathrm{~A} * *$ & $7.6 \mathrm{a} \mathrm{A}$ & $1.12 \mathrm{bc} \mathrm{A}$ & $4.15 \mathrm{a} \mathrm{A}$ & $18.56 \mathrm{a} \quad \mathrm{A}$ \\
\hline & Fox 11 & $3.6 \mathrm{bc} \mathrm{A}$ & $6.9 \mathrm{bc} \mathrm{C}$ & $1.21 \mathrm{~b} \quad \mathrm{~A}$ & 2.29 e C & $17.08 \mathrm{abc} \mathrm{AB}$ \\
\hline & $\mathrm{OH} x \mathrm{~F} 333$ & $3.6 \mathrm{bc} \mathrm{A}$ & $7.4 \mathrm{a} \quad \mathrm{B}$ & 0.99 de $B$ & $4.15 \mathrm{a} \mathrm{A}$ & $17.92 \mathrm{ab} \quad \mathrm{AB}$ \\
\hline & Seedling & $3.5 \mathrm{~cd} \mathrm{~A}$ & $7.0 \mathrm{~b} \quad \mathrm{C}$ & $0.91 \mathrm{e} B$ & $3.70 \mathrm{~b} \mathrm{~B}$ & $16.02 \mathrm{c} \quad \mathrm{B}$ \\
\hline \multirow[t]{4}{*}{ Williams } & BA29 & $3.3 \mathrm{~d} \mathrm{C}$ & $6.1 \mathrm{f} B$ & $1.20 \mathrm{~b} \quad \mathrm{~B}$ & $2.55 \mathrm{~d} \quad \mathrm{~B}$ & $14.07 \mathrm{~d} \quad \mathrm{C}$ \\
\hline & Fox 11 & $3.7 \mathrm{~b} \mathrm{~B}$ & 6.5 de $A B$ & $1.33 \mathrm{a} \quad \mathrm{A}$ & $2.21 \mathrm{e} \mathrm{C}$ & $16.51 \mathrm{bc} \quad \mathrm{B}$ \\
\hline & $\mathrm{OH} x \mathrm{~F} 333$ & 3.9 a A & 6.4 ef $\mathrm{AB}$ & $1.08 \mathrm{~cd} \mathrm{C}$ & $3.37 \mathrm{c} \mathrm{A}$ & $17.69 \mathrm{abc} \mathrm{AB}$ \\
\hline & Seedling & $4.0 \mathrm{a} \mathrm{A}$ & $6.7 \mathrm{~cd} \mathrm{~A}$ & $1.03 \mathrm{~cd} \mathrm{C}$ & $3.59 \mathrm{bc} \mathrm{A}$ & $18.73 \mathrm{a} \quad \mathrm{A}$ \\
\hline \multicolumn{7}{|c|}{ Factors' means } \\
\hline \multirow[t]{4}{*}{ Rootstocks } & BA29 & $3.5 \mathrm{~b}$ & $6.88 \mathrm{a}$ & $1.16 \mathrm{~b}$ & $3.35 \mathrm{~b}$ & $16.31 \mathrm{~b}$ \\
\hline & Fox 11 & $3.7 \mathrm{a}$ & $6.67 \mathrm{~b}$ & $1.27 \mathrm{a}$ & $2.25 \mathrm{c}$ & $16.79 \mathrm{ab}$ \\
\hline & $\mathrm{OH} x \mathrm{~F} 333$ & $3.8 \mathrm{a}$ & $6.88 \mathrm{a}$ & $1.04 \mathrm{c}$ & $3.76 \mathrm{a}$ & $17.81 \mathrm{a}$ \\
\hline & Seedling & $3.7 \mathrm{a}$ & $6.84 \mathrm{ab}$ & $0.97 \mathrm{c}$ & $3.65 \mathrm{a}$ & $17.38 \mathrm{ab}$ \\
\hline \multirow[t]{2}{*}{ Cultivars } & Deveci & $3.6 \mathrm{~b}$ & $7.23 \mathrm{a}$ & $1.06 \mathrm{~b}$ & $3.57 \mathrm{a}$ & $17.40 \mathrm{a}$ \\
\hline & Williams & $3.7 \mathrm{a}$ & $6.42 \mathrm{~b}$ & $1.16 \mathrm{a}$ & $2.93 \mathrm{~b}$ & $16.75 \mathrm{a}$ \\
\hline
\end{tabular}

\subsubsection{Leaf length}

In the study, the highest leaf length was in the BA29 (6.88 $\mathrm{cm})$ rootstock and the $\mathrm{OHxF} 333(6.88 \mathrm{~cm})$ rootstock and the lowest in the Fox11 $(6.67 \mathrm{~cm})$ rootstock. The leaf length of 'Deveci' cultivar $(7.23 \mathrm{~cm})$ was higher than 'Williams' (6.42 $\mathrm{cm})$ cultivar. In terms of rootstock x cultivar interaction, the highest leaf length was in the 'Deveci'/BA29 $(7.6 \mathrm{~cm})$ and 'Deveci'/OHxF333 $(7.4 \mathrm{~cm})$ and the lowest was in the 'Williams'/BA29 $(6.1 \mathrm{~cm})$ rootstock (Table 2).

\subsubsection{Petiole diameter}

Petiole diameter varied between $0.97 \mathrm{~mm}$ and $1.27 \mathrm{~mm}$ in the rootstock and between $1.06 \mathrm{~mm}$ and $1.16 \mathrm{~mm}$ in the cultivar. The petiole thickness was found to be the highest in the Fox $11(1.27 \mathrm{~mm})$ and the lowest in the seedling rootstock $(0.97 \mathrm{~mm})$ and the OHxF333 $(1.04 \mathrm{~mm})$ rootstocks. The petiole diameter of 'Williams' cultivar was higher than the 'Deveci'. In the study, the highest leaf petiole thickness was found in the 'Williams'/Fox11 (1.33 mm), and the lowest was in the 'Deveci'/seedling $(0.91 \mathrm{~mm})$ in terms of rootstock $\mathrm{x}$ cultivar interaction (Table 2 ).

\subsubsection{Petiole length}

The highest petiole length was found on the OHxF333 (3.76 $\mathrm{cm})$ and the seedling $(3.65 \mathrm{~cm})$ rootstocks and it was the lowest on the Fox11 $(2.25 \mathrm{~cm})$ rootstock. The petiole length was higher in the 'Deveci' cultivar $(3.57 \mathrm{~cm})$ than the 'Williams' cultivar $(2.93 \mathrm{~cm})$. In terms of rootstock $x$ cultivar interaction, petiole length was the highest on the
'Deveci'/BA29 (4.15 cm) and 'Deveci'/OHxF333 $(4.15 \mathrm{~cm})$ and the lowest was on the 'Williams'/Fox11 $(2.21 \mathrm{~cm})$ rootstock/scion combinations (Table 2).

\subsubsection{Leaf area}

In the study, rootstocks and rootstock x cultivar interaction had a statistically significant effect on the average of the leaf area, while the cultivars had an insignificant effect. In terms of rootstock averages, the highest leaf area was in the OHxF333 $\left(17.81 \mathrm{~cm}^{2} \mathrm{leaf}^{-1}\right)$ and the lowest was in the BA29 $\left(16.31 \mathrm{~cm}^{2}\right.$ leaf $\left.^{-1}\right)$ rootstock. In terms of rootstock x cultivar interaction, the highest leaf area was determined in the 'Deveci'/BA29 (18.56 $\mathrm{cm}^{2}$ leaf $\left.{ }^{-1}\right)$ and 'Williams'/seedling $\left(18.73 \mathrm{~cm}^{2}\right.$ leaf $\left.^{-1}\right)$ and the lowest was in the 'Williams'/BA29 $\left(14.07 \mathrm{~cm}^{2}\right.$ leaf $\left.^{-1}\right)$. The highest leaf area of the 'Deveci' cultivar was on the BA29, and the lowest was on the seedling rootstock. The highest leaf area of the 'Williams' cultivar was on the seedling and the lowest was on the BA29 rootstock (Table 2 ).

\section{Discussion}

In this study, rootstocks and cultivars and rootstocks $\mathrm{x}$ cultivars interaction have a significant effect on the lateral branch numbers in the shoot (Table 1). To obtain yields from fruit trees at an early age, well-branched and wide-angle saplings are required (Buban 2000; Magyar et al., 2008). The trees in the orchards set up with this kind of saplings form more flower buds in the first years and yield higher quality 
fruit (Rom and Carlson, 1987). Cetinbas et al. (2018) reported that the number of lateral branches in the shoot was higher in the 'Deveci' than the 'Santa Maria', and the highest lateral branch number was obtained from 'Deveci'/ OHxF97 and 'Santa Maria'/OHxF333. Rahman et al. (2017) cited that rootstocks and cultivars had significant effects on the number of lateral branch per sapling in nursery conditions. Irisarri et al (2016) determined the lowest number of lateral branches in the 'Williams'/BA29 scion/rootstock combination. Rahmati et al. (2015) reported that the number of lateral branches of pear cultivars grafted on different rootstocks varied between 1.0-10.7 number plant-1. Karlidag et al. (2016) found that the number of lateral branches in the pear ranged between 3.69-9.21 number plant-1. In this study, the significant effects of rootstocks and cultivars with genetic differences on each other's growth and development caused the number of lateral branch in the main shoot to be different. In fact, it was emphasized that rootstock and cultivars with different growth and development characteristics may have different number of shoots (Irisarri et al., 2016; Rahman et al., 2017; Cetinbas et al., 2018). In addition, rootstocks and cultivars that dwarfed develop in terms of growth vigor may have higher number of lateral branch. It has been emphasized that different cultivars and rootstocks can affect the growth of shoots and show different growth characteristics (Rom and Carlson, 1987; Rahman et al., 2017).

In the grafted plants, it is stated that especially the balance between auxin and cytokine can be effective on the lateral branch number (Hratko and Magyar, 2004). Auxin increases main shoot development and it reduces lateral shoot development (Taiz and Zieger, 2008). However, a cessation that may occur in the growth or enter the dormancy of the bud at the top of the main shoot causes the side buds to continue. This reduction in the dominance of auxin causes with increasing of cytokine and this effect is increases to the emergence of lateral buds and lateral branch number (Shimizu-Sato et al., 2009). However, since the auxins produced at the top of the shoots cannot be carried to the lateral buds, auxins have no direct effect on the growth of the lateral buds (Leyser, 2003; Ongaro and Leyser, 2008). On the other hand, cytokine has direct effects on lateral bud growth, as cytokine produced in the nodes on the main shoot are transported directly to the lateral buds and growing lateral buds increase significantly (Ongaro and Leyser, 2008; Taiz and Zieger, 2008; Shimizu-Sato et al., 2009). Graft components may reduce the transport of certain substances, such as hormones (eg, auxins), from scion to down rootstock or, vice versa, from rootstock to scion (Dun et al., 2006). As a result, the amount of cytokine transported from the roots of the sapling to the shoot may be higher, and the number and growth of the lateral shoots may increase as the lateral shoots suck more cytokine.

It has been reported that the length of the lateral branches decreases in the saplings with high number of lateral branches and this decreasing occurs due to the competition of the high number of lateral branches (Rossi et al., 2004). Sahin (2014) reported that the length of the lateral branch varied of sweet cherry cultivars and the branch length was between $19.3 \mathrm{~cm}$ and $29.6 \mathrm{~cm}$ among the cherry cultivars. The results of this study are in accordance with the results of
Rahmati et al. (2015) and Karlidag et al. (2016) who noted lateral branch length varied between $25.5 \mathrm{~cm}$ and $52.1 \mathrm{~cm}$ in the pear. Tatari et al., (2020) cited that the highest lateral shoot length in the quince was in the BA29 and Quince seedling, the lowest was in the QC and the hawthorn rootstocks. The dwarfed rootstocks shorten the length of trees by decreasing annual shoot length compared to vigor rootstocks (Jackson, 2003). Ozturk and Ozturk (2014) reported that the tree height was higher in the BA29 rootstock than the MC and pear seedling rootstocks. They stated that this was due to the fact that the dwarfed rootstocks grow faster than the rootstocks due to the better root structure of the trees until they start to yield. Rootstocks affect the transport of carbohydrates and nutrients between roots and branches. In addition, rootstocks, growth regulators, carbohydrates and nutrients affect the distribution and vegetative development of the plant (Rufato et al., 2014). Rahmati et al. (2015) cited that apple and pear rootstocks have been to be effective in controlling tree size, dwarf rootstocks reduce tree canopy size, and low root volume of dwarf rootstocks leads to reduced shoot growth. The rootstock can affect to the transfer of nutrients and carbohydrates between the roots and branches. Also, the rootstock influences the distribution of carbohydrates, elements, and growth regulators and affects the vegetative growth of the plant (Rufato et al., 2014). Jackson (2003) reported that apple and pear rootstocks were effective in controlling tree size and dwarfing rootstocks reduced tree size and the low root volume of dwarfing rootstocks results in reduced shoot growth.

The diameters of the lateral branches and the crotch angles between main shoots and them are significant criteria that determine the quality of the produced sapling and the age of fruiting (Rom and Carlson, 1987). The number of lateral branches with scion/stock combinations is low, it was observed that the lateral branch length and lateral branch thickness were slightly higher. Karlidag et al. (2016) found that lateral branch diameter varied between 4.8-6.3 $\mathrm{mm}$ in pear saplings. Sahin (2014) reported that cultivars have an effect on the lateral branch diameter and it ranged between $4.49 \mathrm{~mm}$ and $5.04 \mathrm{~mm}$ among the sweet cherry cultivars. In this study, the highest lateral branch diameter was in the seedling rootstock and it was the lowest in the Fox 11 rootstock. It can be said that the lateral branch diameter is higher in the vigorous rootstocks than dwarf rootstocks. The results obtained from this study are compatible with the previous studies.

Pear trees have many different shoot growth shapes such as upright, semi-upright, broad, drooping. Pear saplings can be distributed immediately after planting the main branches on the trunk to form a well-canopy structure (Ozcagiran et al., 2005). The angle between these main branches and the trunk determines the shape of the canopy. Wide-angle branches with strong bonding between the trunk and the lateral branches of the tree can carry the excessive fruit load without breaking. However, branches with narrow angles between the trunk and the lateral branches have weak joints and cannot carry the excessive fruit load without breaking (Jackson, 2003). Rootstocks influence on branch angle and the dwarf rootstocks have a larger branch angle than the semi-dwarf rootstocks (Warner, 1991). In addition, dwarf 
rootstocks both make wider angled branches and form a smaller canopy than vigor rootstocks (Rom and Carlson, 1987). The branch angle affects not only the vegetative development of the tree, but also its precocity. Saplings with wide-angled lateral branches provide better distribution of light in the canopy and are precocity than seedlings with narrow-angled branch structure (Jackson, 2003; Srivastava et al., 2013). It was determined that the crotch angle between the trunk and the lateral branches varied between 30.7-52.20 in pear (Karlidag et al., 2016). Sahin (2014) stated that there was a difference in terms of lateral branch angle among sweet cherry cultivars and the angle of lateral branch varied between 42.97-44.37. He reported that the amount of increased cytokine may have increased the angle between the lateral shoots and the trunk. The cytokine carried up from the root can increase the lateral branch angle as well as increase the lateral branch development (Hratko and Magyar, 2004; Taiz and Zieger, 2008). In this study, it was determined that quince rootstocks make a more wide-angle branch than pear rootstocks. This situation may have resulted from different development characteristics of rootstocks. Pear rootstocks, which form narrower angles and strong shoots compared to quince rootstocks, develop stronger by causing more upright shoot growth. In addition, pear clonal rootstocks develop slightly stronger than quince clone rootstocks (Jackson, 2003; Hancock and Lobos, 2008; Dondini and Sansavini, 2012).

The rootstocks and cultivars and rootstock $\mathrm{x}$ cultivar interaction had significant effect on the leaf width in this study (Table 2). Serttas (2019) cited that pear cultivars had significant effect on the leaf width and rootstocks had not significant effect on the leaf width of the pear cultivars grafted on different pear rootstocks and the leaf width varied between 3.34 and $3.75 \mathrm{~cm}$. Ozturk and Ozturk (2014) reported that the rootstocks had a significant effect on the leaf size of the "Deveci" pear, and the leaf width was the highest in saplings grafted on the BA29 rootstock. Vegetative growth and development increase as the optimum ecological conditions of the region where the plants are grown positively affect the photosynthesis level (Uzun, 1997). The leaf width results of this study were found to be consistent with previous studies.

In the present study, there were significant effects of rootstock, cultivar and rootstock $\mathrm{x}$ variety interaction on the leaf length. Serttas (2019) reported that pear rootstocks had a statistically significant effect on leaf length and found that leaf length in rootstock varied between 5.90 and $6.52 \mathrm{~cm}$. Ozturk and Ozturk (2014) noted that the 'Deveci' pear cultivar had a significant effect on the leaf length and the highest leaf length was in the saplings grafted on BA29. Uzun (1997) reported that the ecological conditions, which are optimum level for cultivation, positively affect the photosynthesis in the plant and increase vegetative growth and development. In addition, Zenginbal et al. (2017) reported that the different genetic structures of rootstocks and cultivars caused differences in growth characteristics and thus changed to the leaf size.

There was significant effect of both rootstocks and cultivars and rootstock $x$ variety interaction on petiole length in the study. Ozturk and Ozturk (2014) emphasized that rootstocks had a significant effect on petiole length in the
"Deveci" pear, and that the leaf petiole length varied between $3.35 \mathrm{~cm}$ and $4.43 \mathrm{~cm}$. They reported that the highest average petiole length was in the BA29 quince rootstock $(4.43 \mathrm{~cm})$ and the lowest was in the seedling rootstock $(3.35 \mathrm{~cm})$. The results obtained from this study slightly differ from the results obtained from previous researchers. It can be said that the observed difference was due to the cultivation and management conditions and rootstock used.

In the study, rootstocks and cultivars and rootstock $\mathrm{x}$ variety interaction had statistically significant effect on the leaf petiole diameter. Ozturk and Ozturk (2014) found that rootstocks had a significant effect on the leaf petiole thickness and they cited that leaf stalk thickness varied between 0.58 and $0.76 \mathrm{~mm}$. They reported that the highest petiole thickness was in the BA29 $(0.76 \mathrm{~mm})$ and seedling $(0.70 \mathrm{~mm})$ rootstocks and the lowest was in the EMC quince rootstock $(0.58 \mathrm{~mm})$. The results obtained in this study a bit differ from the results obtained from previous researchers. We can say that the observed difference is due to the cultivation conditions and rootstock used.

Pear rootstocks have an insignificant effect on the average leaf area and pear cultivars have a significant effect and the average leaf area was $14.38-16.61 \mathrm{~cm}^{2} \mathrm{leaf}^{-1}$ for rootstocks and $14.58-17.92 \mathrm{~cm}^{2}$ leaf $^{-1}$ for cultivars (Serttas, 2019). Ozturk and Ozturk cited that the rootstocks have a significant effect on the leaf area in the "Deveci" pear and the highest average leaf area was on the BA29 quince rootstock $\left(16.31 \mathrm{~cm}^{2}\right.$ leaf $\left.^{-1}\right)$. The differences observed in vegetative development in fruit species and cultivars may result from differences in genetic, ecological conditions and cultivation technique (Rom and Carlson, 1987; Jackson, 2003). It can be said that the difference in the average leaf area of pear cultivars grown on the rootstocks with different growth vigor in the same growing conditions is caused by the genetic structure. In fact, Erturk and Guleryuz (2008) and Zenginbal et al. (2017) stated that the differences occurred in vegetative development in the same ecological conditions depend on the different genetic structure of the plants. And also, it can be said that the differences in the leaf size and growth vigor of the cultivars caused this situation. In the research, the differences in leaf area between pear cultivars may be due to the very similar leaf shape of the cultivars.

\section{Conclusion}

In this study, the effects of rootstocks and cultivars on some vegetative properties of 'Deveci' and 'Williams' pear cultivars grafted on quince and pear rootstocks were determined rootstocks and cultivars had significant effects on lateral branch and leaf characteristics of pear cultivars grafted on different rootstocks. It was determined that the number of lateral branches was higher in $\mathrm{OHxF} 333$, lateral branch diameter and was higher in the seedling rootstocks and the branch angle was lower in the BA29 rootstock. Generally, the leaf and lateral branch characteristics were higher in the 'Deveci' cultivar than the 'Williams'. This study demonstrated that the cultivars grafted on different rootstocks affect their growth and development by affecting their vegetative development. For this reason, knowing the vegetative development characteristics of the rootstock/cultivar combination to be selected while selecting rootstocks and varieties to be used in the pear orchard facility 
will make it easier to manage the cultural applications to be applied in the orchard.

\section{Authors' Contributions}

Nermin Coban conduced this MSc study under supervision of Ahmet Ozturk. The supervisor planned and wrote this article.

\section{Conflict of Interest}

The authors declare that they have no conflict of interest.

\section{References}

Buban, T. (2000). The use benzyladenine in orchard fruit growing: a mini review. Plant Growth Regul. 32(2-3), 381390.

Cetinbas, M., Butar, S., Sesli, Y., \& Yaman, B. (2018). Effects of different cultivar/rootstock combinations on the some seedling characteristics for pear nursery growing. J. Agr. Fac. of Gaziosmanpasa University. 35(special issue), 8-12.

da Silva, G. J., Villa, F., Grimaldi, F., da Silva, P. S., \& Welter, J. F. (2018). Pear (Pyrus spp.) Breeding, Volume: 3, 131164. In: J.M. Al-Khayri, S.M. Jain, D.V. Johnson (edts). Advances in Plant Breeding Strategies: Fruits. Gewerbestrasse 11, 6330 Cham, Switzerland. doi: 10.1007/978-3-319-91944-7 4

Dondini, L., \& Sansavini, S. (2012). European pear. In: M.L. Badanes, and D.H. Byrne (eds). Springer, New York. pp.369-413. doi: 10.1007/978-1-4419-0763-9_11

Dun E. A., Ferguson B. J., \& Beveridge C. A. (2006). Apical dominance and shoot branching. Divergent opinions or divergent mechanism? Plant Physiol. 142, 812-819.

Erturk, Y., \& Guleryuz, M. (2008). Bazı yerli ve yabancı kayısı çeşitlerinin erzincan koşullarındaki vejetatif ve generatif gelișme durumlarının belirlenmesi. Atatürk Üniversitesi Ziraat Fakültesi Dergisi, 39(1), 9-14.

Gulen, H., Arora, R., Kuden, A., Krebs, S. L., \& Postman, J. (2002). Peroxidase isozyme profiles in compatible and incompatible pear-quince graft combinations, J. Amer. Soc. Hortic. Sci. 127(2), 152-157.

Gundogdu, (2019). Effect of rootstocks on phytochemical properties of apricot fruit. Turk J Agric For, 43, 1-10.

Hancock, J. F., \& Lobos, G. A. (2008). Pears. In:J.F. Hancock (ed.). Temperate Fruit Crop Breeding: Germplasm to Genomics. Springer, New York. p299-335.

Hartmann, H. T., Kester, D. E., Davies, Jr. F. T., \& Geneve, R. L. (2011). Plant propagation: principles and practices. 8th ed. Regents/Prentice Hall International Edition. Englewood Cliffs, New Jersey.

Hepaksoy, S. (2019). Meyvecilikte Anaç Kullanımı: Armut Anaçları. Türk Bilimsel Derlemeler Dergisi, 12 (2), 69-74.

Hrotko K., \& Magyar L. (2004). Effect of depth of planting/budding height and solar radiation exposure of 'M.26', 'MM.106' rootstocks and 'B.9'/'MM' interstems on the growth and yield of 'Idared' apple trees. Acta Hortic. $658,69-73$

Hudina, M., Orazem, P., Jakopic, J., \& Stampar, F. (2014). The phenolic content and its involvement in the graft incompatibility process of various pear rootstocks (Pyrus communis L.). J. Plant Physiol. 171, 76-84.

Irisarri, P., Pina, A., \& Errea, P. (2016). Evaluation of the vegetative characteristics and graft compatibility of pear varieties grafted on 'BA-29' and 'OHF-87' rootstocks. ITEA, 112(3), 243-254.
Jackson, J. E. (2003). Biology of apples and pears. Cambridge University Press, Cambridge, UK.

Karlidag, H., Eren, G., Karaat, F. E., \& Kan, T. (2016). Grafting height effects on lateral branching, shoot angles and growth of some fruit species saplings. Int. J. Agric. Innov. Res. 5(2), 262-265.

Lewis, W. J., \& Alexander, Mc E. D. (2008). Grafting \& Budding. A Practical Guide for Fruit and Nut Plants and Ornamentals. Landlinks Press, Australia.

Leyser, O. (2003). Regulation of shoot branching by auxin. Trends Plant Sci. 8, 541-545.

Magyar, L., Barancsi, Z., Dickmann, A., \& Hrotko, K. (2008). Application of biostimulators in nursery. Bulletin UASVM, Hortic. 65(1):515-519.

Ongaro, V., \& Leyser, O. (2008). Hormonal control of shoot branching. J. Exp. Bot. 59, 67-74.

Ozcagiran, R., Unal, A., Ozeker, E., \& Isfendiyaroglu, M. (2004). Pear, In: Temperate Fruit Trees, Pome Fruits (Vol. II). Ege Univ. Agriculture Faculty Publications, Number: 556, pp: 73-126. Izmir, Turkey (in Turkish).

Ozturk, A., \& Ozturk, B. (2014). The rootstock influences growth and development of 'Deveci' Pear. Turk J Agric and Natural Sci. 1, 1049-1053.

Ozturk, A., Demirsoy, L., \& Demirsoy, H. (2017). New leaf area estimation model in pear. International Conference on Computational and Statistical Methods in Applied Sciences, 9-11 November 2017, Abstract Book, 300, p 232, Samsun, Turkey.

Pina, A., \& Errea, P. (2009) Morphological and histochemical features of compatible and incompatible stem unions. Acta Hortic. 814, 453-456.

Rahman, J., Aftab, M., Rauf, M. A., Rahman, K. U., Bilal, W., \& Ayub, F. G. (2017). Comparative study on compatibility and growth response of pear varieties on different rootstocks at nursery. Pure Appl. Biol. 6(1), 286-292.

Rahmati, M., Arzani, K., Yadollahi, A., \& Abdollahi, H. (2015). Influence of Rootstock on Vegetative Growth and Graft Incompatibiiity in Some Pear (Pyrus spp.) Cultıvars. IndoAmer. J. Agric. \& Vet. Sci. 3(1), 25-32.

Rom, R. C., \& Carlson, R. F. (1987). Rootstocks for fruit crops. Wiley and Sons. New York.

Rossi, A. D., Rufato, L., Giacobbo, G. L., Gomez, F. R. C., \& Fachinello, J. C. (2004). Use of promalin on one-year-old trees of the Apple cv. 'Catarina', Acta Hortic. 636, 145-149.

Rufato, L., Machado, B.D., Kretzschmar, A. A., Bogo, A., Luz, A. R., \& Marcon Filho, J. L. (2014). Effect of high plant density on growth and production variables of european pear cultivars and quince rootstock combinations in southern Brazil. Acta Hortic. 1058, 71-76.

Sahin, M. (2014). Effects of promalin and mulching on lateral branching in sweet cherry. Master's Thesis, Selçuk University, Institute of Science and Technology, Konya.

Serttas, S. (2019). Bazı Armut Klon Anaçları Üzerine Aşılı Armut Çeşitlerinin Fidan Gelişim Performanslarının Belirlenmesi. Yüksek Lisans Tezi, Ondokuz Mayıs Üniversitesi, Fen Bilimleri Enstitüsü, Samsun.

Serttas, S., \& Ozturk, A. (2019). Bazı Armut Klon Anaçları Üzerine Aşılı Armut Çeşitlerinin Fidan Gelișim Performanslarının Belirlenmesi. KSÜ Tarım ve Doğa Derg, 23 (4), 842-850.

Sharma, S., Rehalia, A. S., Sharma, S. D. (2009). Vegetative growth restriction in pome and stone fruits. Agric. Rev. 30(1), 13-23.

Shimizu-Sato S., Tanaka M., \& Mori H. (2009). Auxin- 
cytokinin interactions in the control of shoot branch. Plant Mol. Biol. 69, 429-435.

Srivastava, K. K., Singh, S. R., Das, B., \& Sharma, M. K. (2013). Influence of branch angles on branch diameter and fruit expansion of apricot. Indian J. Hort. 70(2), 206-210.

Taiz, L., \& Zeiger, E. (2008). Bitki Fizyolojisi; İsmail Türkan (edt), Palme Yayıncilık, Ankara, pp. 423-515.

Tatari M., Rezaei, M., \& Ghasemi, A. (2020): Quince Rootstocks Affect Some Vegetative and Generative Traits. Int. J. Fruit Sci.1-15.

TSMS. 2020. Turkish State Meteorological Service Official Web Sites. 01 May 2020. https://mgm.gov.tr.

Uzun, S. (1997). Sıcaklık ve 1şı̆̆ın bitki büyüme, gelişme ve verimine etkisi (I. Büyüme). Ondokuz Mayıs Üniversitesi Ziraat Fak. Dergisi, 12(1), 147-156.
Warner, J. (1991). Rootstock affects primary scaffold branch crotch angle of apple trees. Hortscience. 26(10), 1266-1267.

Webster, A.D. (1995). Rootstock and interstock effects on deciduous fruit tree vigour, precocity, and yield productivity. New Zealand J. Crop Hortic. Sci. 23(4), 373382.

Westwood, M.N. (1995). Temperate-zone pomology, physiology and culture. 3rd ed., Timber Pres, Oregon.

Zenginbal, H., Demir, T., Demirsoy, H., \& Beyhan, O. (2017). The grafting success of fourteen genotypes grafted on three different rootstocks on production of sweet cherry (Prunus avium L.) sapling. Acta Sci. Pol-Hortoru. 16(1), 133-143.

Turkish Journal of Food and Agriculture Sciences is licensed under a Creative Commons Attribution-NonCommercial-NoDerivatives 4.0 International License 